\title{
Relationship between domestic debt, macro-economic indices and viability of the Construction sector in Nigeria
}

\author{
Ademola Eyitope, OJO ${ }^{1, ~ *}$, Oluwaseyi Alabi, AWODELE ${ }^{2}$ \\ ${ }^{1}$ Physical Planning Department, Federal University, Oye Ekiti. Nigeria \\ ${ }^{2}$ Department of Quantity Surveying, Federal University of Technology, Akure Nigeria \\ Email address: \\ Ojconnect2@yahoo.com(A. E. OJO); deledayo4christ@yahoo.com (O. A. AWODELE)
}

\section{To cite this article:}

Ademola Eyitope, OJO, Oluwaseyi Alabi, AWODELE. Relationship between Domestic Debt, Macro-Economic Indices and Viability of the Construction Sector in Nigeria. International Journal of Economics, Finance and Management Sciences.

Vol. 1, No. 6, 2013, pp. 266-272. doi: 10.11648/j.ijefm.20130106.12

\begin{abstract}
This study aimed at establishing relationship between domestic debt, macroeconomic indices and the viability of the construction sector of Nigeria economy with a view to initiate empirical model for investor's decision making. Archival data on monetary and fiscal macroeconomic indices such as unemployment rate; exchange rate; inflation rate; interest rate; domestic debt and the contribution of the construction sector to the GDP between years 2001-2011 were collected from Nigeria Bureau of Statistics (NBS) and Central Bank of Nigeria (CBN) official gazette. The data were analyzed using multiple regression analysis to establish the relationship that exists between the identified fiscal macroeconomic variables. The analysis revealed that the adjusted $\mathrm{R}^{2}$ of 0.629 or $63.0 \%$ of the Viability of the Construction Sector (proxy by Construction industry sector GDP growth rate(GDP ci)) is explained by the selected macroeconomic variables. While this study conclusion avail for long-run behavior of the economy and challenges of investment decision as it affects construction business, it recommended that appropriate guidance and understanding of macroeconomic policy is required by investors and policy makers for decision making and attracting investment to the building and construction subsector of the economy.
\end{abstract}

Keywords: Domestic Debt, Construction Industry, Macroeconomic Indices, Nigeria and Viability

\section{Introduction}

The huge natural and human potentials in Nigeria suitably attract investors. In fact, existing incentives such as the $140 \%$ percent capital allowance in research development, 20 percent capital allowance for five years on local raw materials utilization, as well as 30 percent tax relief and expenditure on public infrastructure, offered foreign investment effort (Nigerian Investment Promotion Commission Act NIPC, 1995; Foreign Exchange Monitoring \& Miscellaneous Provisions Act, 1995) remain attractive.

Furthermore, various economic liberalization programmes such National Economic Empowerment and Development Strategy (NEEDS), Vision20: 20:20 etc driven by reform policies of Nigerian government have no doubt informed a prospect for investors. Notably is the world acclaimed reforms in the banking sector by the Central Bank of Nigeria (CBN), which seems to have increased the domestic and international confidence in the Nigerian Economy, with some acclaimed promising macroeconomic variables e.g. stable naira exchange rate and improved growth rate. Factually, since the advent of democratic governance in Nigeria in 1999 to date, government officials particularly governors, ministers and the presidents have not relent in crafting and issuing out policies aimed at private sector participation- imploring and inviting private sector investment in the economy.

This however have challenges especially in Nigeria's business terrain, build huge pressure around these potentials -including infrastructural deficit, poor economic variables etc. This is shown (Oladipo and Oni, 2011) in the slow pace of infrastructural development, and has attracted questioning and becoming a concern. el Rufai, (2011) explained why cost of production has remained high, industrial productivity has decline, low construction activities, abandoned projects with its stern consequences on the nation's socio-economic and technological development. Moreover, this disquiet in numerous debates continue to heave national questions that whether the Nigerian government can fix these deplorable situation with non-impacting economic policies in the face of lingering financial and emerging macroeconomic crisis.

On the financial economic front, national debt stock has 
surged into financial dilemmas to both public and private sectors with the domestic debt stock of the nation (Federal Government of Nigeria (FGN), which is at alarming N6.54trillion (Debt Management Office (DMO), 2012). Critical enough and impacting on the Nigeria citizenry, international image and possibly, scaring interested investors in the economy particularly construction subsector. Somoye and Ilo, (2009) exerted that economic policies, to a large extent, depicts aggregate economic behaviours and mimic macroeconomic environment, such that, for example lending by banks and inflation rate will be a reflection from the economy, influencing investing decision and the viability of prospecting investing economy sector.

More importantly, the increasing and impairing effects of macroeconomic indices over the years posit an apprehension on the construction industry. Grim macroeconomic imbalances have emerged in Nigeria over the last years (IMF, 2001) with current accelerated double-digit inflation rate (11.7\%), exchange rate(N160 to US \$1), low gross domestic product (GDP)(6.3\%), unemployment $23.7 \%$,Money supply/demand Price Stability(7\%) and interest rate $(23 \%)$ resulting into poverty level $(54.4 \%)$ National Bureau of Statistics (NBS), 2011) and low capacity utilization etc. However, the general performance of the economy is reflected by these aggregate macroeconomic indicators and valuates the viability of the economy particularly as affecting construction industry sector in Nigeria which continues to perform abysmally.

\subsection{Objective of the Study}

This study is set out to identify and investigate the trend of these highlighted scenario, to wit; the relationship between macroeconomic indices and construction sector performance, and whether instability in the macroeconomic environment impacts positively or otherwise on the viability of the Nigerian Construction industry as observed by (Kaming et al, 1997) in the developing market as bases for investing decision making.

\section{Review of Literature}

\subsection{Overview of Nigeria's Public Debt Profile}

The history of public sector debt in Nigeria predated 1960. Sanusi (2003) chronicled the national debt from \$23million (1.0\%GDP in 1960), N8, 231.5 million (16.2\% GDP in (1980) and subsequently reaching N1, 160 billion (83.6\%GDP in 2002) and stood at \$6.54Trillion (17.8\% GDP) (December, 30th, 2012) (DMO, 2012). This (Udoka and Ogege ,2012) position excludes contractor debts and supplier credit owed by the government, by way of unhonoured contractual payment certificates, which are estimated at about N1.1Trillion (\$650million). This trend may continue as $\$ 7.2 \mathrm{Billion}$ has been appropriated in the 2013 budget as short and medium term (2013-2015) fiscal years' projected loan requirement out of which the provision for domestic borrowing is N565 billion(\$3.67Billion).
Money market instruments play an important role in Nigerian domestic debt stock through Treasury Bills, Treasury Certificate, Bond, Development Stock, Ways and Means Advances etc which (Adofu and M. Abula, 2010) provide alternative funding options to capital market, a more collateralled means for banks and financial institutions to allocate their surplus savings accordingly, important in monetary policy implementation, help boost a virile financial market (Okonjo-Iweala, 2011)and attract household and institutional savings Sanusi, (2003). DMO, (2012) revealed that Nigerian Treasury Bills account for N2.8Trillion(33.6\%), Federal Government Bond stands at N3.7Trillion(61.1\%), Treasury Bond N353.73 (5.3\%) of domestic debt stock.

Actually, no system has sufficient resources to meet ever increasing socio-economic needs due to demand pressure. Sanusi, (2010) declining revenue from mono-commodity oil dominance economy resulted in growing and large fiscal deficits and need for domestic debt accumulation. Budgetary appropriation for energy need increased significantly (Adenikinju, 2011) with N261.1 billion (1.4\% GDP), 278.9billion (1.3\% GDP), N1.1Trillon spent in 2006,2007 and 2011 respectively, and proposed N980Billion in 2013 budget on subsidy due mainly to rising oil price and depreciating exchange rate. The need (Gbosi, 1998) to finance rising government expenditures due to long time neglect and decaying infrastructure system and(Udoka and Ogege, 2012) political instability have been identified to be responsible for the rapid increase in the stock of Nigeria's domestic debt and sufficient to scare away foreign investors, thereby reducing per-capital gross domestic product and increasing debt profile in Nigeria.

The cumulative consequences of this debt overhang have not only been impairing significantly (Christensen, 2004) on interest rate payment on debt servicing, unstable fiscal and monetary policy, but (Sanusi, 2003) created serious obstacles economic growth and development, (Ositelu,2012) informs a narrow investors base and duly crowd out private investing participation, while raising lending rate.

\subsection{Issues on Macroeconomic Indices}

Virtually all sectors of an economy are generally influenced by many factors amongst which are statutory regulations and policies, and macroeconomic indices. The statutory regulatory and policies environment involves government policies, laws, guidelines and rules issued mostly periodically e.g. fiscal and monetary policies. However, economic environment is persuaded by the more exigent financial, social, industrial etc vagaries e.g. macroeconomic indices. Macroeconomic indicators such as unemployment rate, exchange rate, inflation rate, capacity utilization, external debt and price stability etc are systematic risk component of the economy (Asaolu and Ogunmakinwa, 2011), which influence and affect every participant and sector within the economy. However, little is still known about the relationship between domestic debt, macroeconomic indices and the Construction Sector of the 
Nigerian economy unlike other sectors.

Oladipo and Oni (2012) investigated the impact of macroeconomic indicators on the prices of building materials (in Nigeria) with a view to enhancing construction project procurement and delivery. They revealed that critical indicators affecting the prices of building materials include inflation rate, exchange rate, import, interest rate and money supply. Olaniyan (2000) also indicated that inflation and its variability are part of the important indicators of macroeconomic instability in Nigeria with significant negative impact on investment. Investigation of banks lending behavior by (Somoye and Ilo, 2009) implicated macroeconomic variables and their instability to have concern at the long-run on the industry and the other economic sectors.

The relative effectiveness of fiscal and monetary policy in macroeconomic management in Nigeria (Ajisafe, and Folorunso, 2002) reveal that though monetary rather than fiscal policy exerts a great impact on economic activity in Nigeria, however the emphasis on fiscal action of the government has led to greater distortion in the Nigerian economy, and opined that both monetary and fiscal policies should be complementary. Hence, the contribution of building and construction sector to GDP continues to decline, (Sanusi, 2010) owing to vagaries of economic environment, government fiscal policies and international pressure. Though Nigeria government has repeatedly announced that macroeconomic environment has improved considerably, but (MDG Report, 2010) growth has not generated enough jobs and its effect on poverty and business climate is not yet clear.

\subsection{Selected Macroeconomic Indices}

Historically, the central bank benchmark interest rate, which is the Monetary Policy Rate (MPR) on loans by commercial banks. Nigeria interest rate averaged $16.75 \%$ over years 2001-2009, with a record low of $16.89 \%$ in 2006 , but reaching an all time high of $21.0 \%$ in 2011 and climaxed $22.5 \%$ in 2012. Soludo (2008) argued that Nigeria's real and nominal lending rates are not outliers relative to some selected countries but is dominantly explained by the depth of financial markets, level of inflation, risks and uncertainty. AIAE(2003) emphasized that the market determined (liberalization) of the interest regime informed large spread between deposit and lending rates with the persistent high real interest rate for borrowers and very low rates for depositors, hence a central challenge to investors.

Again, exchange rate stability goal is of the monetary policy and over the years has been driven by many factors like demand for imports, inflation rates, government fiscal policies instruments etc. Omole, (2001) indicated the extent of distortions in the market and inhibits private sector investment. Also, with the large pool of youthful and trained labour force in Nigeria, unemployment rate is high. Unemployment rate (National Bureau of Statistics (NBS), 2012) increased to 23.90 percent in 2011 from 21.10 percent in 2010, from moving average record low of 5.3\% in 2006 to
2007, until 2011 averaged 14.6\%. Stressing further that for persons between ages 15 and 24 years, $41.6 \%$ were unemployed and between 25 and 44 years, $17 \%$ were unemployed as at March 2009. This is informed by distorted power supply, low industry capacity and cost of production leading to serious insecurity.

A study by (Fatukasi, 2008) revealed Nigerian economy is endemic with high inflation rate and remain a concern to all including government despite various policies to combat it. In year 2000, inflation rate was $6.9 \%$, increased to $17.9 \%(2005)$ and $13.8 \%(2010)$, being grossly influenced by variation in the Naira value, lending interest rate, demand pull and limited supply of goods etc. The Gross Domestic Product (GDP) measures the total market value of all final goods and services produced in a country i.e. (investwords,2012) total consumption, investment and government spending, plus the value of exports, minus the value of imports in a given year- GDP expressed sectorally shows the strength of a nation's economy. In Nigeria, (Soludo, 2008) despite the jump in oil prices, aggregate GDP growth rate before 2002 has averaged 3.4 percent, with per capita income growth rate of $0.6 \%$ which appears better than the average of $2.8 \%$ for the decade of the 1990 s yet far below the minimum growth rate of 5\% required preventing poverty. However, an aggregate GDP growth rate has improve over the years; particularly from 2005 until 2012, averaged $6.8 \%$ reaching an all time high of $8.6 \%$ in 2010 and expanded $7.10 \%$ in 2012 while gravitating towards the required $7-8 \%$ to achieve the MDG by 2015 .

These indicators interact greatly and by this make impact on the economy. For example, reduction of interest rates should bring increase in business activity, reduces unemployment level and increases industrial capacity and vice viser; while a rise in inflation rate weakens national currency, increases exchange rate, lowers level of business activity and is likely to drop employment creation. This is exemplified by great sectoral share of GDP and growth performance.

\subsection{Structure and Importance of the Construction Industry}

The construction industry, which undertakes infrastructural projects, contributes about half of the total stock of national fixed capital investment and generates employment opportunities in the Nigeria economy. In 1981, the building and construction subsector of the economy accounted for $5.8 \%$ of Nigeria's GDP but, the sub-sector's contributions to GDP growth continue to decline- ranked fifth in GDP in 1985 and 1986 (7.3\%), and suffered a setback in 1998 when it ranked sixth (7.2\%)( Oyejide and Bankole, 2001) and 2.34\% and $1.43 \%$ in 2001 and 2012 respectively. The Nigerian construction industry is one sector that has the economic potential of contributing over $15 \%$ growth to the nation's GDP within the next nine years (2020). El- Rufai (2011) and Oforeh C. (2006) argued that infrastructure is critical to human and economic development and is the catalyst for attracting investment, for 
which Nigeria has enormous potentials due to her huge deficit in infrastructure.

However, for longer time government will continue to be the main client, financier and promoter of the construction industry sector through provision of public infrastructure.

Building and construction activities and statistics covers building, civil and heavy engineering subsectors (Ofore, 2006) and NBS(2002) data on works undertaken in building subsector with projects not limited to residential, industrial, health, institutional, market etc buildings with their adjoining facilities like electrical, security and mechanical installations (building services)etc. Civil projects include road, railway, marine work etc, while heavy engineering project involve, jackets, pipelines, power station, renting of construction or demolition equipment with operators etc. a given period. However, (Ojo,2011) most of purported foreign and domestic loan facilities obtained by government were meant for infrastructural development yet the construction services sectors of the economy remain the weak and do not impact on the economy.

\subsection{Effects of Domestic Debt and Macroeconomic Indices on the Construction Sector}

Increased public domestic debt, particularly the failure of government and some multi-national companies to meet their financial obligations of funding capital projects has led to over 100,000 job losses in the past one year (Eroke, 2011), while a large number of construction companies and construction sites have either closed down or project abandoned due to heavy debt contracts by all tiers of government. Oladipo and Oni (2012) Material prices have inflated over the years resulting in (Aibinu and Jagboro, 2002) project cost overrun frequent in Nigerian construction market. Also, default payment has forced many contractors to borrowing from commercial banks at high interest rate in order to execute projects. These and other factors have made the Building and Construction sector contribute on the average of $1.8 \%$ to GDP between years 2001-2009.

\section{Methodology}

This study is based on the economic model representing the basic features of the alighted economic phenomenon. The specification of the model is based on the multiple regression analysis of the time series secondarily available selected macroeconomic indices information relevant viz: unemployment rate, exchange rate, inflation rate, domestic debt as percentage of GDP, interest rate and GDP growth rate, forming the variables on which effort has been made on their theoretical and empirical issues underlying them as a determinant of viability of the construction sector of the economy. The data were obtained from NBS and CBN official information/bulletins for the period between years 2001 to 2011.

\subsection{Research Design and Hypotheses}

The research adopted an experimental research design approach, which combines theoretical and empirical observation of the data. The monetary and fiscal variables for the research were selected by convenience buttressed by theoretical observation of the data.

This is to emphasis the relationship/differences of the variables based on the selected macroeconomic indices.

\subsection{Empirical Model Analysis}

Given the nature of this study, little is still known about the relationship between domestic debt, macroeconomic indices and the Viability of the Construction Sector of the economy. Hence, Viability of the Construction Sector function adopted in the study combined monetary and fiscal variables thus:

$$
\mathrm{C}_{\mathrm{v}}=\mathrm{f}(\mathrm{UeR}, \mathrm{ExR}, \mathrm{InR}, \mathrm{DmD}, \mathrm{ItR})
$$

Where,

$\mathrm{C}_{\mathrm{v}}=$ Viability of the Construction Sector(proxy by Construction industry sector

GDP growth rate(GDP ci)).

$\mathrm{UeR}=$ Unemployment rate,

$\mathrm{ExR}=$ Exchange rate,

$\mathrm{InR}=$ Inflation rate,

$\mathrm{DmD}=$ Domestic debt \% of GDP,

$\mathrm{ItR}=$ Interest rate

However, taken the linear approximation or ecnometric of equation (1), the model becomes;

$$
\mathrm{C}_{\mathrm{v}}=\alpha_{0}+\alpha_{1} \mathrm{UeR}+\alpha_{2} \mathrm{ExR}+\alpha_{3} \operatorname{InR}+\alpha_{4} \mathrm{DmD}+\alpha_{5} \mathrm{ItR}+\ldots .
$$

But equation (2) above is exact or deterministic in nature. However, to allow for the inexact relationship among the variables as in the case of most economic variables, stochastic error term " $\mu_{\mathrm{t}}$ " is added to equation(2) thus:

$$
\mathrm{C}_{\mathrm{v}}=\alpha_{0}+\alpha_{1} \mathrm{UeR}+\alpha_{2} \mathrm{ExR}+\alpha_{3} \operatorname{InR}+\alpha_{4} \mathrm{DmD}+\alpha_{5} \mathrm{ItR}+\mu_{\mathrm{t}}
$$

\subsection{Data Analysis and Presentation}

To analyze data shown on table 1 below, multiple regression statistical methods was used. This helped to show the relationship between the independent (explanatory) variables and the dependent variable. In other words, the model estimated the influence of domestic debt and macroeconomic indices on the Viability of the Construction Sector (proxy by GDP of construction Industry).

\section{Findings and Discussions}

The results presented in the table 1 above show the common coefficients across the variables observed. Four (4) of the variables, namely: Unemployment rate, (UeR), Interest Rate (IntR) Inflation rate(Infr), and Domestic debt $\%$ of GDP,(DmD) are found to be statistically significant at 5\% significant level. Though they all exert a 
negative impact on Construction industry sector GDP growth rate (GDP ci) in contrast to our priori assumption to exert positive effects. However, Exchange rate (ExR) exert a positive impact but not statistically significant in this study. The adjusted $\mathrm{R}^{2}$ of 0.629 shows that about $63.0 \%$ of the Viability of the Construction Sector (proxy by Construction industry sector

GDP growth rate (GDP ci)) is explained by the selected macroeconomic variables. The F-Statistics of 0.334 indicates the significance and good fit of the variables.

Model Specification: Since this model was developed to access the Relationship between domestic debt, macro-economic indices and viability of the Construction sector in Nigeria with data between 2001 - 2011, to achieve robust statistical analysis specified regression model runs as follows:

$$
\begin{gathered}
\mathrm{C}_{\mathrm{v}}=\alpha_{0}+{ }_{\alpha 1}(0.004)_{\mathrm{UeR}}+\alpha_{2}(0.016) \mathrm{ExR}+\alpha_{3}(0.035) \mathrm{InR}+\alpha_{4} \\
(0.013) \mathrm{DmD}+\alpha_{5}(0.034) \mathrm{ItR}+\mu_{\mathrm{t}}
\end{gathered}
$$

This equation indicates that regression coefficient of interest rate in the estimated regression line is negative 0.035 , depicting a unit rise in interest rate led to $3.5 \%$ point decrease in Construction industry sector GDP growth rate (GDP ci).

Table 1: Selected Macroeconomic Indices

\begin{tabular}{lllllll}
\hline YEAR & GDPci & UemR & ExR & IntR & InfR & DmDR \\
\hline 2001 & 0.56 & 3.60 & 111.90 & 18.29 & 18.90 & 36.60 \\
2002 & 0.78 & 12.60 & 120.97 & 24.85 & 12.90 & 26.10 \\
2003 & 0.85 & 14.80 & 129.35 & 20.71 & 22.20 & 26.10 \\
2004 & 1.60 & 13.40 & 133.50 & 19.18 & 14.50 & 28.60 \\
2005 & 1.50 & 11.90 & 131.66 & 17.95 & 17.90 & 20.80 \\
2006 & 1.59 & 13.70 & 128.50 & 16.89 & 8.20 & 18.60 \\
2007 & 1.67 & 14.60 & 127.80 & 16.94 & 5.90 & 19.20 \\
2008 & 1.75 & 14.90 & 139.60 & 15.97 & 11.60 & 11.60 \\
2009 & 1.82 & 11.30 & 151.00 & 19.55 & 12.50 & 15.20 \\
2010 & 1.45 & 19.10 & 154.00 & 15.74 & 13.70 & 18.00 \\
2011 & 1.99 & 23.90 & 157.00 & 16.75 & 12.80 & 17.90 \\
\hline
\end{tabular}

Sources: Nigeria Bureau of Statistics and Central Bank of Nigeria official information/bulletins for the period between years 2001 to 2011

Table 2: Analysis of Independent (Explanatory) Variables

\begin{tabular}{llllll}
\hline & $\begin{array}{l}\text { Coeffic } \\
\text { ients }\end{array}$ & $\begin{array}{l}\text { Standard } \\
\text { Error }\end{array}$ & t Stat & P-value & $\mathbf{9 5 \%}$ \\
\hline C & 0.644 & 1.930 & 0.334 & 0.752 & 5.605 \\
UemR & -0.004 & 0.029 & -0.135 & 0.898 & 0.070 \\
ExR & 0.016 & 0.013 & 1.309 & 0.248 & 0.049 \\
IntR & -0.035 & 0.040 & -0.870 & 0.424 & 0.067 \\
InfR & -0.034 & 0.026 & -1.338 & 0.239 & 0.031 \\
DmDR & -0.013 & 0.023 & -0.571 & 0.593 & 0.046 \\
\hline
\end{tabular}

Table 3: Regression Analysis Summary output.

\begin{tabular}{ll}
\hline Regression Statistics & \\
\hline Multiple R & 0.902 \\
R Square & 0.814 \\
Adjusted R Square & 0.629 \\
Standard Error & 0.285 \\
Observations & 11 \\
\hline
\end{tabular}

This means marginal increase in cost of production and hence decreases in supply of goods and services, with evidence of increase cost of doing business and discouragement to investment decisions. This underscores (Aibinu and Jagboro, 2002) that critical factor causing the interest rate are government economic policies, and value of money in circulation.

Within the period under review, exchange rate has negative estimated regression line of 0.016 , which shows that a unit increase in exchange rate led to $1.6 \%$ point decrease in Construction industry sector GDP growth rate (GDP ci). This is significant in the currency devaluation policy of the Naira, leading to looses in its value, making importation expensive for equipment acquisition and discourages foreign good consumption. However, this position enhances local industry capacity growth, export and Foreign Direct Investment (FDI).

Domestic Debt and it repayment has been a significant issue in Nigeria economy. From this analysis, Domestic debt \% of GDP,(DmD) exerted negative 0.013 estimated regression, which indicate a unit increase in Domestic debt $\%$ rate led to $1.3 \%$ point decrease in Construction industry sector GDP growth rate (GDP ci). This may not be a surprise because over N585Billion was appropriated to Domestic debt repayment in 2011 fiscal years which meant stagnation to development of essential infrastructures. Government domestic borrowing has been on the significant increase and has crippled honoring of contract payment certificate (Ojo, 2012).

Unemployment rate in Nigeria economy has been a concern. With an estimated regression line is 0.004 , which shows that a unit decrease in unemployment rate led to $0.4 \%$ point decrease in Construction industry sector GDP growth rate (GDP ci). This means that inability of many other factors to stimulate the economy resulted in many job not been created while existing once are loss. This is as a result of multiple effects of factors like poor money supply, inflation, deregulation of interest rate (Somoye and Ilo, 2009).

From the analysis, Inflation rate also exerts a 0.034 point negative but significant impact on Construction industry sector GDP growth rate (GDP ci). This means 1 unit growth in inflationary rate makes the Construction industry sector GDP to reduce by $3.4 \%$ per cent. It supports further and confirms (Olaniyan, 2000) that inflation rate variability had a negative and significant impact on investment in Nigeria.

These findings not only indicate the relationship between 
Construction industry sector GDP growth rate (GDP ci)) and the selected macroeconomic indices/ variables but that the variables thus jointly account for modifications of Nigerian construction industry activities in the short run and long run and attest to its non viability.

\section{Conclusion/Recommendation}

Though Nigeria has huge natural and human potentials to attract investors, the challenge in the business terrain builds huge pressure around domestic debt and macroeconomic indices. The study attracted critical consideration because very limited attention has been paid to the area of macroeconomics of construction market in Nigeria and therefore pertinent that some empirical evidence is provided. Relationship between macroeconomic indices and the viability of the Construction sector in Nigeria become important for investor's decision making. While reviewing literature, the analysis of the time series properties of the selected macroeconomics indicators data revealed that most of the indices were in integrated order evidence from the regression analysis. It therefore shows that GDP rate of the construction sector and the explanatory variable have a long run relationship for viability of the construction sector investment decision in Nigeria.

It is strongly recommended that investors in the construction sector understand long-run behavior of the economy as to investment decision making and be appropriately guided by macroeconomic policy formulations. Also, policy makers in Nigeria must be mindful of the correlation between building and construction sector of the economy and macroeconomic variables such as interest rate, exchange rate by formulating policies. This will enable sufficient and time decision making for investors and growth of the Nigerian economic condition.

Also Government fiscal responsibilities should be more transparent especially in the use of domestic borrowing and particularly to indulge in the massive investment in infrastructure which in turn will attract participation of investors in public procurement. Financially, savinginvestment gap often creates investors' confidence and by extension, foreign exchange earnings should be annexure and monitored to ensure development of real sector of the economy hence increasing aggregate demand.

\section{References}

[1] Adofu and M. Abula(2010) Domestic Debt and the Nigerian Economy, Current Research Journal of Economic Theory 2(1): $22-26$,

[2] African Institute For Applied Economics (2003). Nigeria: Macroeconomic Assessment and Agenda for Reforms Report. www.aiae.abs.net retrieved 12/02/ 2013

[3] Ajisafe, R.A., And Folorunso, B.A.(2002). The Relative Effectiveness Of Fiscal And monetary Policy In Macroeconomic Management In Nigeria. The African
Economic And Business Review, 3(1)23-40

[4] Aibinu A.A. and Jagboro G.O. (2002)." The effects of construction delays on project delivery in Nigerian construction industry". International Journal of Project Management 20 593-599

[5] Asaolu T.O. and Ogunmakinwa M. S. (2011), 'An Econometric Analysis of the Impact of Macroeconomic Variables on Stock Market Movement in Nigeria' Asian Journal of Business Management, 3(1), 72 - 78.

[6] Central Bank of Nigeria (CBN) (2008). Annual Report and Statement of Accounts.

[7] Central Bank of Nigeria (CBN) (2002). Annual Report and Statement of Accounts.

[8] Debt Management office 2012 http://www.dmo.gov.ng retrieved 20/12/2012

[9] el-Rufai N. (2011). Still on Infrastructure Deficits. Thisday Newspaper, www.onlinethiday.com retrieved 5/8/2011

[10] Eroke L (2011).Nigeria: Heavy Debt, Job Losses Limiting Construction Industry Http://Allafrica.Com/Stories. Retrieved 14/08/2012

[11] Foreign Exchange Monitoring \& Miscellaneous Provisions Act(1995) No. 17.

[12] Gbosi, A.N.(1998). The impact of Nigeria's domestic debt on macroeconomic environment. First Bank Review Journal.

[13] investorwords: www.investorwords.com/2240/gross_domestic_product. accessed 05/03/2013

[14] Kaming, P. F., Olomolaiye, P. O., Holt, G. D., and Harris, F. C (1997). "Factors influencing construction time and cost overruns on high-rise projects in Indonesia." Construction Management Economy. 15(1), 83-94

[15] Millennium Development Goals(2010) Nigeria MDG 2010 Federal Government Report,

[16] National Bureau of Statistics (NBS)(2011)

[17] Nigerian Investment Promotion Commission Act NIPC(1995) No. 16, 1995

[18] Ojo A.E. (2011). The Multiplier Effects of Challenges of the Downstream Oil and Gas Sector on the Infrastructure Development in Nigeria. Paper Delivered at the National Seminar of The Nigerian Institute of Quantity Surveyors, (Ondo State Chapter),on Towards Achieving Effective Costing in Infrastructures Development. Hilltop Hall, Federal University of Technology, Akure on 4th and $5^{\text {th }}$, July.

[19] Okonjo-iweala N. (2012).”Nigeria external and Domestic Debt Now is \$44B". http://www.thisdaylive.com Retrieved $17 / 4 / 2012$

[20] Okonjo-Iweala N.(2010). 'Nigeria's rising domestic debt profile' http://www.nigerianbestforum.com.Retrieved 26/12/ 2012

[21] Oladipo, F.O. And Oni, O. J.(2012). A Review Of Selected Macroeconomic Factors Impacting Building Material Prices In Developing Countries A Case Of Nigeria. Ethiopian Journal Of Environmental Studies And Management (EJESM).5( 2). 
[22] Olaniyan O.(2000) The Effects of Instability on Aggregate Investment in Nigeria. The NigerianJournal of Social and Economic Studies, vol.42, no1. March, pp.23-26.

[23] Omole, A. O. (2001), The Factors that Determine the Cost of Building. Materials Paper presented at a 2- Day National Seminar on "Building Materials --which Alternatives?" at Abuja.

[24] Soludo, C. 1999. "Growth Models and Regional Divergence: Implications for Public Policy in Nigeria". African Economic Research Consortium Discussion Papers.

[25] Soludo, C. (2008). Issues On The Level Of Interest Rates In Nigeria,

www.cenbank.org/out/speeches/2008/govadd30-6-08. Accessed 05/03/2013
[26] Sanusi O. J.(2003). Management Of Nigeria's Domestic Debt .A Keynote Address Delivered at the 7th Monetary Policy Forum organised by the Central Bank of Nigeria at the CBN Conference Hall, Abuja, 22 May .

[27] Sanusi L. S.(2010). Growth Prospects for the Nigerian Economy, Convocation Lecture delivered at the Igbinedion University Eighth Convocation Ceremony, Okada, Edo State, November 26,

[28] Somoye and Ilo(2009)The Impact of Macroeconomic Instability on the Banking Sector Lending Behaviour in Nigeria. Journal of Money, Investment and Banking - Issue 7,88-100

[29] Udoka C. O. and Ogege S (2012).'Public Debt and the Crisis of Development in Nigeria Econometric Investigation." Asian Journal of Finance and Accounting.4 (2)1-13 